\title{
Disaster Tips for People with Disabilities ${ }^{1}$
}

\section{Carolyn S. Wilken ${ }^{2}$}

Natural disasters such as tornadoes, floods, and hurricanes create special challenges for people with disabilities, their caregivers, and their families. People with disabilities need to have the same basic disaster supply kit as everyone else. Basic supply lists are available from a number of sources, but the list available at the American Red Cross web site serves as the model

(http://www.redcross.org/disaster/safety/fds-all.pdf). People with disabilities may have special needs that go beyond the basic supplies list. The following tips were recommended by the U.S. Departments of Homeland Security and the Federal Emergency Management Agency for people with disabilities.

The suggestions in this factsheet are for adults with disabilities who are able to independently prepare for a disaster. If you are making preparations for someone else see Tips for Caregivers of People with Disabilities ( http://edis.ifas.ufl.edu/FY751).

\section{Make Your Lists}

- Emergency Information List

- Medical Information List

- List of doctors, relatives, or friends who should be notified if you are hurt (include phone numbers and addresses)
- Disability Related Supply List

- List of the style and serial number of medical devices

- Emergency Document List

See the publication titled Disaster Planning Tips for Senior Adults http://edis.ifas.ufl.edu/FY620 for additional suggestions of items to add to your supply list.

\section{Put Your Needs in Writing}

Create a detailed description of your specific needs including:

- Daily routine

- Special instructions about medications (i.e., must be crushed, cut tablets in half, place crushed tablet in applesauce, what to do if you've missed a dose, etc.)

- Actions that cause extra pain, nervousness, or distress (i.e., lying flat on your back without a pillow under your knees, loud noises, etc.)

1. This document is FCS9215, one of a series of the Family Youth and Community Sciences Department, Florida Cooperative Extension Service, Institute of Food and Agricultural Sciences, University of Florida. Original publication date: August 2005. Visit the EDIS Web Site at http://edis.ifas.ufl.edu 2. Carolyn S. Wilken, Ph.D., M.P.H., Associate Professor, Family, Youth and Community Sciences, IFAS, University of Florida.

The Institute of Food and Agricultural Sciences (IFAS) is an Equal Opportunity Institution authorized to provide research, educational information and other services only to individuals and institutions that function with non-discrimination with respect to race, creed, color, religion, age, disability, sex, sexual orientation, marital status, national origin, political opinions or affiliations. U.S. Department of Agriculture, Cooperative Extension Service, University of Florida, IFAS, Florida A. \& M. University Cooperative Extension Program, and Boards of County Commissioners Cooperating. Larry Arrington, Dean 


\section{Your Service Animal}

Make plans for your service animal to remain with you. Prepare written instructions for how to handle and care for your service animal.

- Set aside a 2 week supply of food for your service animal

- Include related documents with emergency information

\section{Let Family and Friends Know What You Need}

- Create a support network to help you in an emergency.

- Tell your support network where you keep your emergency supplies.

- Give one member of your support network a key to your house or apartment.

- Contact your city or county government's emergency information management office. Many local offices keep lists of people with disabilities so they can be located quickly in case of an emergency.

- Let your utility company know of your needs, especially if you depend on electricity to operate medical equipment. They can let you know if the electricity will be disconnected for routine service and may also make your home a priority to get you reconnected as soon as possible.

- Wear medical alert tags or bracelets to help identify your disability.

- If you are dependent on dialysis or other life sustaining treatment, know the location and availability of more than one facility where you can receive treatment.

- Find out the location of the special needs evacuation centers nearest you. Know how to get there from your home.

- Show others how to operate your medical equipment such as your oxygen or your wheelchair.
- Know the size and weight of your wheelchair and whether or not it is collapsible, in case it has to be transported.

\section{Keep Extra Supplies on Hand}

- Prescription medicines, list of medications including dosage, list of any allergies

- Extra eyeglasses and hearing-aid batteries

- Extra wheelchair batteries, oxygen, etc ...

- Medical insurance and Medicare cards

\section{Act at the First Sign of Trouble}

Prepare well in advance for potential disasters or emergencies. Are they tracking a hurricane way out in the ocean? Are there warnings of tornados or flooding? If so, then its time to put your personal disaster plan into action. As you know, it may take extra time for you to move to a safe location or to get your things together so do not hesitate.

\section{References}

FEMA: Disaster Preparedness for people with disabilities. Retrieved June 10, 2005, from http://www.fema.gov/library/disprepf.shtm

Homeland Security. ReadyAmerica: Get a kit. Retrieved June 10, 2005, from: http://www.ready.gov/special_needs_items.html

Red Cross Disaster Supplies Kit. Retrieved June 10, 2005, from http://www.redcross.org/services/disaster/0,1082, 0_3_,00.html

Wilken, Carolyn. Disaster Tips for Caregivers of People with Disabilities. Retrieved August 8, 2005, from http:/edis.ifas.ufl.edu/FY751

Wilken, Carolyn. Disaster Planning Tips for Senior Adults. Retrieved August 8, 2005, from http://edis.ifas.ufl.edu/FY620 